\title{
$\mathrm{Cu}-\mathrm{Al}_{2} \mathrm{O}_{3}$ 内部酸化合金の高温内部摩擦およびクリープ
}

\author{
須藤 一*宇野照生 ${ }^{* *}$ 中村義一***
}

Hajime Suto, Teruo Uno and Giichi Nakamura : High Temperature Internal Friction and Creep of Internally Oxidized Copper-Aluminum Alloys. A great deal of work has been made on the high-temperature creep of dispersion-strengthening alloys, and some precipitation strengthening alloys show that the activation energy of creep is very large as compared with the activation energy of self-diffusion in the matrix metal. In order to understand the mechanism controlling the high temperature creep of dispersion-strengthening alloys and usual precipitation-strengthening alloys, the high temperature internal friction and creep of internally oxidized copper-aluminum alloys were investigated. The results obtained are as follows: The dislocations joining hard particles remain very stable even after high-temperature annealing. The activation energies of steady state creep and of the relaxation process of the damping peak at about $750^{\circ} \mathrm{C}$ were $84 \mathrm{kcal} / \mathrm{mol}$ and $70 \mathrm{kcal} /$ mol, respectively. It has been predicted that these activation processes are both in a non-conservative motion of pin-downed dislocation bound directly on the hard particle surface.

(Received July 11, 1969)

\section{I. 緒霉}

金属括よび合金の高温クリープの活性化エネルギーは, その金属中に和ける原子の抁散の活性化エネルギーにほぼ 等しいことがよく知られて㧍り ${ }^{(1) \sim 6)}$ ，クリープの素過程 に原子の㹡散が直接関与していることはほぼ定説となって

* 東北大学工学部金属材料工学科 (Department of Metallurgy, Faculty of Engineering, Tohoku University, Sendai)

** 東北大学大学院, 現在: 住友軽金属工業株式会社 (Graduate School, Tohoku University, Sendai. Present address : Sumitomo Light Metals Co., Ltd., Nagoya)

*** 東北大学大学院, 現在：防衛庁技術研究本部 (Graduate School, Tohoku University, Sendai. Present address : 3 rd Research Center, Technical Research and Development Institute, Defence Agency, Tachikawa)
いる.しかし㜔結アルミニウム合金(SAP)について行なっ た実験によれば，Ansell とWeertman ${ }^{(7)}$ は $150 \mathrm{kcal} / \mathrm{mol}$ ， Meyers とSherby ${ }^{(8)}$ は $190 \mathrm{kcal} / \mathrm{mol}$ とい5大きなりりー プ活性化エネルギーを得ている.これはアルミニウムの自

（1）辛島，及川，渡辺：金属学会会報，5 (1966)，515。

(2) J.Weertman : Transactions Symposium, Dislocation Climb and High Temperature Creep Processes, Trans. ASM., 61 (1968), 680.

(3) J. Weertman : J. Appl. Phys., 20́ (1955) , 1213; 28 (1957) , 362.

(4) C.R.Barrett and W.D.Nix : Acta Met., 13 (1965), 1247.

(5) J.E. Dorn and J. D. Mote : High Temperature Structure and Materials, Pergamon, (1963), 95.

（6）門間，須藤，及川I：金属学会誌，28(1964)，308.

(7) G.S. Ansell and J. Weertman : Trans. Met. Soc. AIME, 215 (1959), 838.

(8) C.L.Meyers and O.D.Sherby : J.Inst. Metals, 90 (1961 2) , 380 . 
己拡散の活性化エネルギー $37 \mathrm{kcal} / \mathrm{mol}^{(1)}$ の約 4 倍の值で ある. Wilcox ら ${ }^{(9)}$ は TD ニッケル $\left(\mathrm{Ni}-2 \mathrm{vol} \% \mathrm{ThO}_{2}\right)$ のク リープ挙動を調ベ, $195 \mathrm{kcal} / \mathrm{mol}$ とい5活性化エネルギー の值を得て拉り，また $\mathrm{Ni}-20 \% \mathrm{Cr}-2 \% \mathrm{ThO}_{2}$ 合金では 92 $\mathrm{kcal} / \mathrm{mol}$ なる值を得ている。.これらの值は， $\mathrm{Ni}$ の自己拡 散の活性化エネルギー，約 $70 \mathrm{kcal} / \mathrm{mol}$ に較べて明らかに 大きい，同じょに高いクリープの活性化エネルギーは， Inーガラス合金です得られている(10).

このような高い活性化エネルギーは，分散強化型合金だ けでなく，通常の耐熱鋼の場合にる認められる。たとえ ば(11)析出物の効果があまり重要と思われない $0.004 \%$ C$18 \mathrm{Cr}-14 \mathrm{Ni}$ および $18 \mathrm{Cr}-12 \mathrm{Ni}-\mathrm{Mo}$ ステンレス鋼のクリー プの活性化エネルギーはそれぞれ $80 \mathrm{kcal} / \mathrm{mol}$ 拉よび 95 $\mathrm{kcal} / \mathrm{mol}$ と比較的自己桩散の活性化土ネルギーに近いが, 析出物の寄与が考乒られる $18 \mathrm{Cr}-12 \mathrm{Ni}-\mathrm{Nb}, 18 \mathrm{Cr}-12 \mathrm{Ni}$ Ti ステンレス鋼のクリープの活性化エネルギーはそれぞ れ $100,140 \mathrm{kcal} / \mathrm{mol}$ なる值を示す。著者らはかって $\mathrm{Cu}$ W 合金(CuとWは互にほとんど固溶しないのクリープを 試験し， $650^{\circ} \mathrm{C}$ に扔いてFig.1のごとさ結果を得た ${ }^{(12)}$.す なわち基質は純銅であるにもかかわらず，分散粒が多くな るほどクリープの活性化エネルギーは大となる。

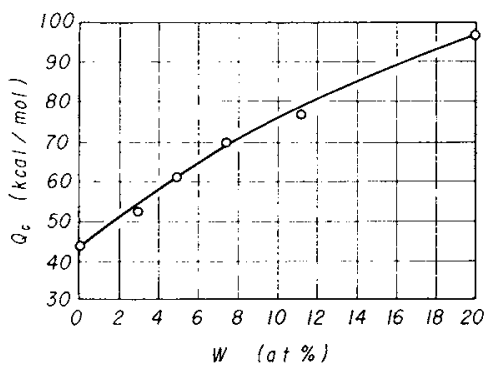

Fig. 1 Activation energy of steady state creep of copper-wolfram alloys

以上の例にみるごとく，粒子を分散させた合金のクリー プの活性化エネルギーは純金属や固溶体の場合と異なり， 地質金属の自己拡散の活性化エネルギーに較べて相当大き いことは明らかである。したがって，そのクリープ機構 は，従来多く発表されている(1)純金属や固溶体のと礼と大 いに異なることが考光られる，実用耐熱合金はほとんど全 て分散粒子を含んでいるので，高温クリープ過程における 粒子と転位の相互作用を知ることは，実用耐熱合金の高温 挙動を理解する5党に重要であるう。

本報では内部酸化法によって得た $\mathrm{Cu}-\mathrm{Al}_{2} \mathrm{O}_{3}$ 合金のクリ 一プ拉よび内部摩擦試験の結果を示乙，分散粒子と転位の 相互作用について，若干の見解を述べる.

(9) B.A.Wilcox, A.H.Clauer and W.S.McCain: Trans. Met.Soc.AIME, 239 (1967), 1791; 236 (1966), 570.

(10) T.D.Gulden and J.C.Shyne: Trans.Met.Soc.AIME, $227(1963), 1088$.

（11）太田：本会第而総合分科，金属敊よび合金のクリー プに関するシンポジウムI (1969)，26.

\section{II. 試料むよび実験方法}

試料素材の $\mathrm{Cu}-\mathrm{Al}$ 合金は電解銅および純フルミニウム

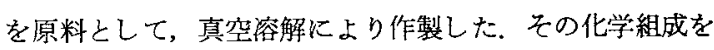
Table 1 亿示す。表中の $\mathrm{Al}_{2} \mathrm{O}_{3}$ vol\%は，陚料中の $\mathrm{Al}$ が

Table 1 Chemical composition

\begin{tabular}{|c|c|c|}
\hline Code & $\begin{array}{c}\mathrm{Al} \mathrm{wt} \% \\
\text { in } \mathrm{Cu}-\mathrm{Al} \text { alloys }\end{array}$ & $\begin{array}{c}\mathrm{Al}_{2} \mathrm{O}_{3} \text { vol \% \% } \\
\text { in } \mathrm{Cu}-\mathrm{Al}_{2} \mathrm{O}_{3} \text { alloys }\end{array}$ \\
\hline $\begin{array}{l}1 \mathrm{~A} \\
3 \mathrm{~A} \\
4 \mathrm{~A}\end{array}$ & $\begin{array}{l}0.098 \\
0.28 \\
0.40\end{array}$ & $\begin{array}{l}0.45 \\
1.37 \\
1.96\end{array}$ \\
\hline
\end{tabular}

* Calcurated from aluminum content in the copper-aluminum alloy

すべて $\mathrm{Al}_{2} \mathrm{O}_{3}$ 沈部酸化されたと仮定して求めた值であ る.試料 $1 \mathrm{~A}, 3 \mathrm{~A}$ 蛙として内部摩擦実験括よび組織観察 用とし， $4 \mathrm{~A}$ はクリープ試験用とした．内部酸化の方法は Rhines ${ }^{(13)}$ と同様に $\mathrm{Cu}$ 粉末, $\mathrm{Cu}_{2} \mathrm{O}$ 粉末, $\mathrm{Al}_{2} \mathrm{O}_{3}$ 粉末を等重 量比に混合したものの中に試料を埋め込み，加熱する方法 を採用した，Fig.2 には，直径 $2 \mathrm{~mm}$ の円柱状試料を用い

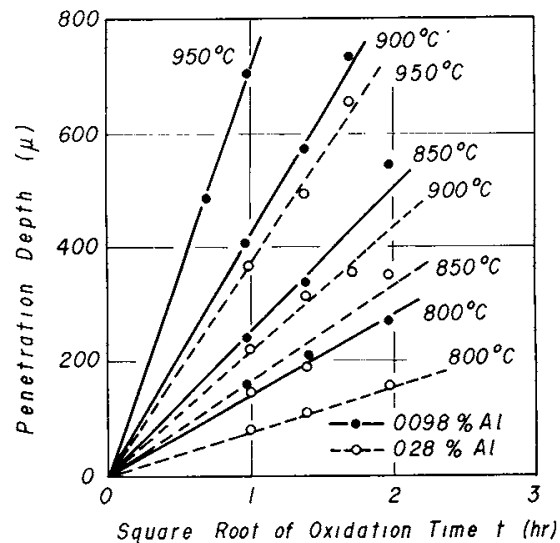

Fig.2 Relationship between penetration depth and oxidation time $(t)$ at various temperatures

て測定した内部酸化時間と酸化層の厚みの関係を示してあ るが，この結果を参照して酸化条件を定めた。すなわち， $1 \mathrm{~A}$ 合金では $900^{\circ} \mathrm{C} \times 1 \sim 2 \mathrm{hr}, 3 \mathrm{~A}$ 合金では $900^{\circ} \mathrm{C} \times 3 \mathrm{hr}$ 以上の加熱を行ない, $4 \mathrm{~A}$ 合金では $950^{\circ} \mathrm{C} \times 48 \mathrm{hr}$ の加熱を 行なった。内部摩擦測定用試料の場合は, 内部酸化後に所 望の冷間加工を行ない，最終線径を一定にすることを考 虑して，0.8，0.75，0.7，0.65 $\mathrm{mm} \phi$ にあらかじめ線引， 焼なまししたものを内部酸化処理を行なった。電子顕微鏡 観察用試料としては $0.2 \mathrm{~mm}$ 板材を用いた。クリープ試験 用試料としては $3 \mathrm{~mm}$ 厚さの板材を用いた。この試料は， 前記内部酸化処理により，中心部に $\mathrm{Al}_{2} \mathrm{O}_{3}$ 分散粒子を含を ない純銅の層が $0.06 \mathrm{~mm}$ の厚又で残存した，中心部に純

(12) 中村：修士論文, 東北大，工 (1964)

(13) N.F.Rhines: Trans. AIME, $137(1940), 246$. 
銅層が残存する理由は, 合金中の $\mathrm{Al}$ が表面に向って拡散 移動し，拡散酸素が試料中心部に到達する以前に，中心部 の $\mathrm{Al}$ が消耗しつくしたためである。このような薄い純銅 層が残存することはクリープ強度を低下させることにな る. しかし純銅の強度は内部酸化 $\mathrm{Cu}-\mathrm{Al}_{2} \mathrm{O}_{3}$ 合金の強度に 較べて数桁小さいので, この中心層の厚みを全厚みから減 じたものを有効厚みと考えて, 応力を求めた(このための クリープ速度の誤差は $10^{-3} \%$ 以下である). 内部摩擦測定 の場合む，この中心層が問題になるはずであるが，実質的 には，中心部でのひずみ量が小さく，そのため中心層の内 部摩擦への寄与が小さいため, 実験值にほとんど影響を及 ぼさないのでこれを無視した。

内部酸化後, 内部摩擦用試料は全て $0.65 \mathrm{~mm} \phi$ になる ように冷間加工を行ない，後述の焼なむしを行なって後測 定に供した。クリープ試験片は内部酸化後 $1.5 \mathrm{~mm} \phi$ まで 冷間加工を行ない, Fig.3 の形状に試料を切り出し，850 ${ }^{\circ} \mathrm{C} \times 1 \mathrm{hr}$ 焼なまし後，試験に供した。

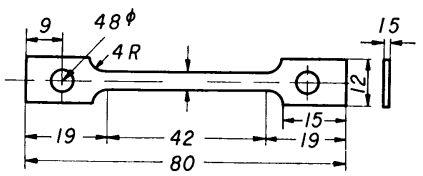

Fig.3- Dimension of creep specimen

クリープ試験機は自家製の直接荷重型であり，加熱 $\mathrm{Ti}$ で脱酸した精製アルゴン気流中でクリープを行なわせ，伸 びをダイアルゲージで読みとった ${ }^{(14)}$. クリープの進行とと もに試料断面積が減少するが，重錘系に付したゴム製べロ 一ズの弾性を利用して, 実質的には拉よそ定応力試験が行 なえるように工夫してある。

内部摩擦の測定は，真空中で，逆吊り㨝り振子法により 行なった. 試料の長さは $15 \mathrm{~cm}$ である. 振動減哀の状況は 写真法により観測した. 装置にとりつけられた鏡と写真印 画紙までの距離は拈よそ $2 \mathrm{~m}$ であり，試料表面の最大ひず 又量は打よそ $3 \times 10^{-5}$ である. 具温速度は毎分 $2^{\circ} \mathrm{C}$ とし， 約 $5^{\circ} \sim 10^{\circ} \mathrm{C}$ 扰き内部摩擦を連続的に測定した。内部摩 擦の大きさは $Q^{-1}$ で表わした。

内部摩擦用試料 と同種の $0.65 \mathrm{~mm} \phi$, 長さ $50 \mathrm{~mm}$ の試 料を用いて, 標点距離 $30 \mathrm{~mm}$, 引張速度 $1 \mathrm{~mm} / \mathrm{min}$ で引 張り試験を行ない, $0.2 \%$ 耐力を求めた.

透過電子顕微鏡観察には次の電解研摩液を用いた。燐酸 $90 \mathrm{vol} \%$, エチルアルコール $10 \mathrm{vol} \%$, 室温.

種々の試料で電解研摩を行なったが, $\mathrm{Al}_{2} \mathrm{O}_{3} \%$ の高い試 料では美麗な薄膜が得られず,このため $1 \mathrm{~A}$ 試料について の観察を行なった。

\section{III. 実 験 結 果}

Fig. 4 は $1 \mathrm{~A}$ 試料を $14 \%$ 冷間加工 $(0.70 \mathrm{~mm} \phi \rightarrow 0.65$ $\mathrm{mm} \phi), 25 \%$ 冷間加工 $(0.75 \mathrm{~mm} \phi \rightarrow 0.65 \mathrm{~mm} \phi), 34 \%$ 冷 間加工 $(0.8 \mathrm{~mm} \phi \rightarrow 0.65 \mathrm{~mm} \phi)$ の後, 種々の温度で $1 \mathrm{hr}$
焼なましたものの引張り耐力值を示す。これにみるごと く，加工度が大なるほど耐力は大となるが，加工度にかか わらず $300^{\circ} \sim 500^{\circ} \mathrm{C}$ の間に明らかな軟化を示す. しかしこ こで内部酸化したままの強度, $14.3 \mathrm{~kg} / \mathrm{mm}^{2}$ に達せず, 強 加工したものほど高い強度を保持し，融点近傍まで焼なま し温度を上げても，この関係は変らない。

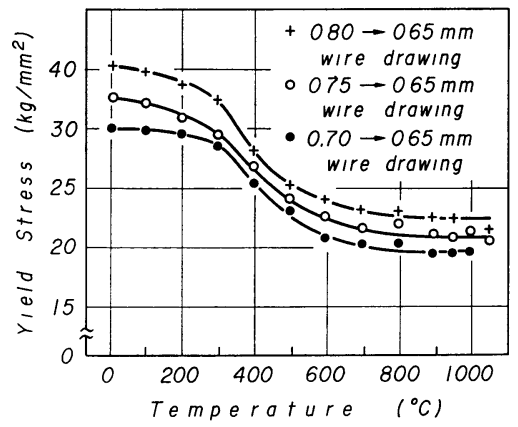

Fig. 4 Yield strength of $1 \mathrm{~A}$ alloy cold worked and followed by annealing at various temperatures for $1 \mathrm{hr}$

この間の転位組織を $34 \%$ 冷間加工材の場合について示 したのが Photo.1〜Photo.7である. まず Photo.1 は内部 酸化したままの組織であるが, $\mathrm{Al}_{2} \mathrm{O}_{3}$ 粒子のまわりにひ ずみ場が認められる。このひずみ場は，一種の coherent strain であるのか，それとも基質と粒子の熱膨張の差にも とづくものかは明らかでない，2 相合金ではしばしば粒子 と基質の差にもとづく dislocation punching 現象が認めら れるが(15) (22)，本合金ではそれらしいるのは見当らない。 これは粒子が十分微細なためであろう。

Photo. 2 は $34 \%$ 引き抜き加工試料の組織である. 多数の 転位が認められるが，これらの転位はすつれ合って，直径 約 0.2 0.3 $\mu$ のセルをつくっている.

Photo.3〜Photo.7 は焼なまし温度の上昇とともに転位 密度が減少していく様子を示す，すなわちセルは消滅する

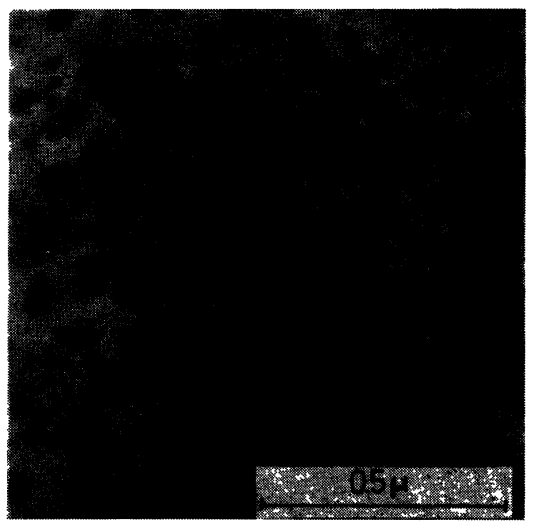

Photo.1 Transmision electron microphotograph of $1 \mathrm{~A}$ alloy. As internal oxidation $(\times 60000 \times 4 / 5)$

(14) 間間, 須藤, 及川：金属学会誌，28 (1964)，253. 


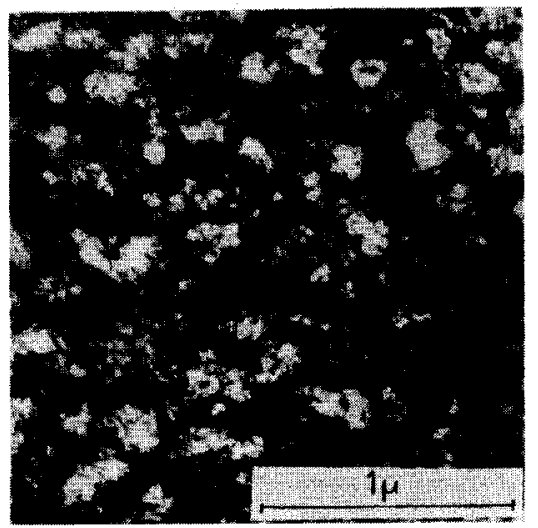

Photo.2 Transmision electron microphotograph of $1 \mathrm{~A}$ alloy. $34 \%$ cold reduction $(\times 30000 \times 45)$

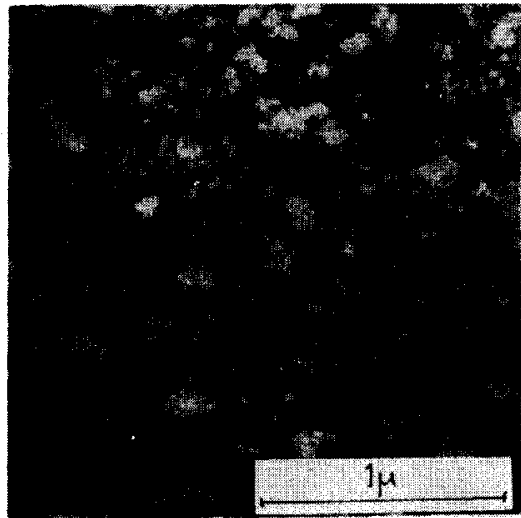

Photo. 3 Transmision electron microphotograph of $1 \mathrm{~A}$ alloy. Annealed at $200^{\circ} \mathrm{C}$ for $1 \mathrm{hr}(\times 30000 \times 4 / 5)$

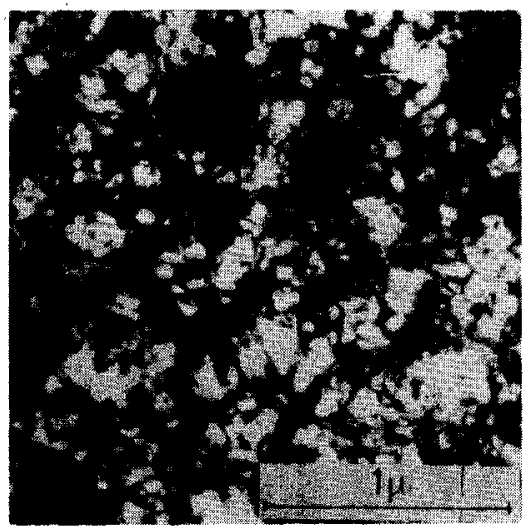

Photo. 4 Transmision electron microphotograph of $1 \mathrm{~A}$ alloy. Annealed at $400^{\circ} \mathrm{C}$ for $1 \mathrm{hr}(\times 30000 \times 4 / 5)$

(15) M.F.Ashby and G.C.Smith : Phil.Mag., 5 (1960), 298.

(16) M. H. Lewis and J. W. Martin : Acta Met., 11 (1963), 1207.

(17) R. S. Goodrich and G. S. Ansell : Acta Met., 12 (1964), 1097.

(18) M.F.Ashby and G. C. Smith : J. Inst. Metals, 91 (1963), 182.

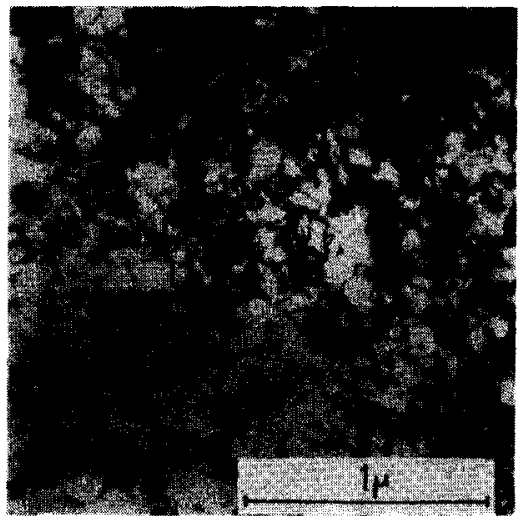

Photo.5 Transmision electron microphotograph of $1 \mathrm{~A}$ alloy. Annealed at $600^{\circ} \mathrm{C}$ for 1 hr $(\times 30000 \times 4 / 5)$

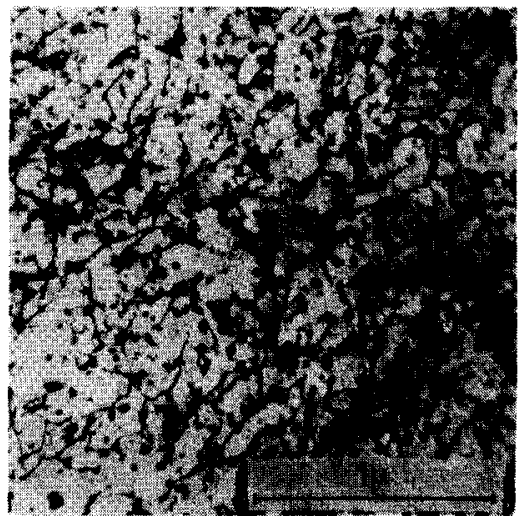

Photo. 6 Transmision electron microphotograph of $1 \mathrm{~A}$ alloy. Annealed at $800^{\circ} \mathrm{C}$ for $1 \mathrm{hr}(\times 30000 \times 4 / 5)$

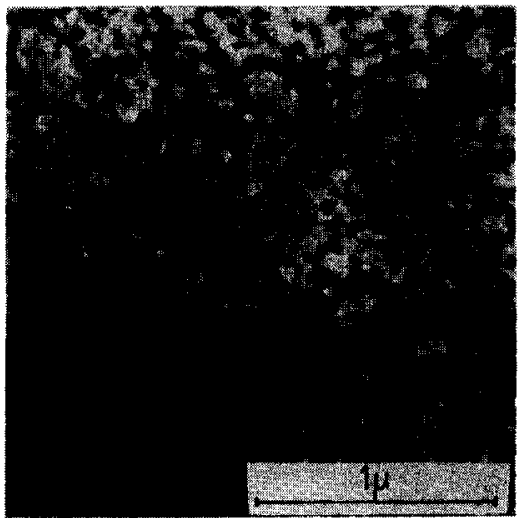

Photo.7 Transmision electron microphotograph of $1 \mathrm{~A}$ alloy. Annealed at $1000^{\circ} \mathrm{C}$ for $1 \mathrm{hr}(\times 30000 \times 4 / 5)$

(19) W.R.Hibbard and E.W.Hart: J.Metals, 7 (1955), 200.

(20) D. A. Jones and A. Kelly : Acta Met., 15(1967), 656.

(21) J.Gurland and J.Plateau: Trans.ASM, 56 (1963), 442 .

(22) 茅野：金属学会誌，31 (1967)，310. 
が，明らかな subgrain は形成されずまた再結晶も起ら ない. $800^{\circ} \mathrm{C}$ 以上の焼なましでは，粒子と粒子を結ぶよう に転位が存在し，これらの転位は $1000^{\circ} \mathrm{C}$ の焼なましによ ってああまり消滅しない。

Fig.5は $4 \mathrm{~A}$ 試料のクリーブ曲線の結果である。これに

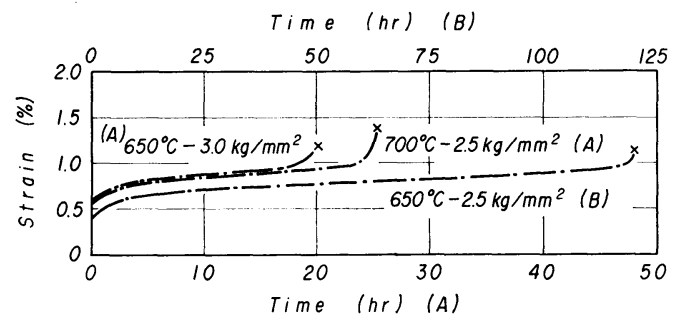

Fig. 5 Creep curves of $4 \mathrm{~A}$ alloy

みるように，一般に定常クリープ段階が長く，加速クリー プ域が小さいことが特徵である.

Fig.6は定常クリープ速度 $\dot{\varepsilon}$ と試験温度 $T$ の関係を示

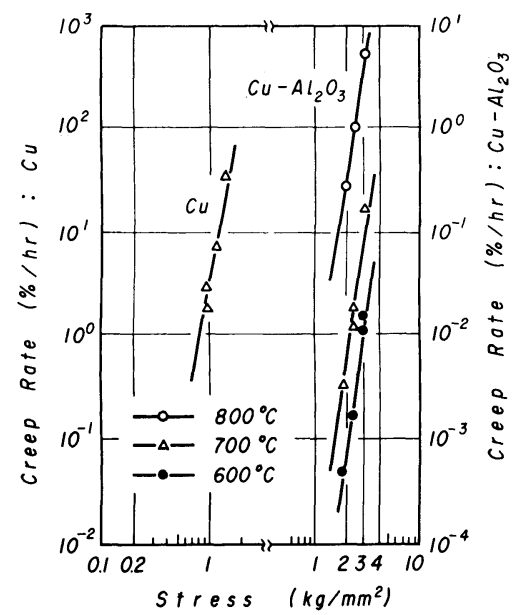

Fig. 6 Relationship between steady state creep rate and testing temperature $T^{\circ} \mathrm{K}$ of $4 \mathrm{~A}$ alloy

す.これらの結果より, 応力 $\sigma, \dot{\varepsilon}, T$ の間には

$$
\dot{\varepsilon}=A \sigma^{n} \exp \frac{-Q_{\mathrm{c}}}{R T}
$$

の関係があり, 活性化エネルギー $Q_{\mathrm{c}}$ は $82 \mathrm{kcal} / \mathrm{mol}$, 応力 指数 $n$ は約 7 であることが判った，純銅の場合は $Q_{\mathrm{c}}=42$ $\mathrm{kcal} / \mathrm{mol}, n=5$ である(23). これらの值に較べて，上記の 内部酸化合金の値が大きいことは，他の種類の分散強化型 合金の場合と定性的に一致する.

次に内部摩擦実験の結果について述べる.

Fig.7 は $1 \mathrm{~A}$ 抢よび $3 \mathrm{~A}$ 合金の内部酸化処理前後の状態 での $Q^{-1}-T$ 曲線を示す。まず内部酸化処理を行なわない $\mathrm{Cu}-\mathrm{Al}$ 合金の場合は, $500^{\circ} \mathrm{C}$ 付近に粒界の粘性流動にもと づく $Q^{-1}$ のピークが認められる。このピークの温度は別に 同様の方法で求めた純銅の場合の $270^{\circ} \sim 300^{\circ} \mathrm{C}$ に較べて

(23) 門間, 須藤, 及川：金属学会誌，28 (1964)，258.
高温側に存在しておりまた $\mathrm{Al}$ 含有量の多いほど高温に ずれる。このような溶質ないし不純物の関与する粒界内部 摩擦ピークについては本論文では深く触れない(24).このよ うに明らかな粒界内部摩擦ピークを示す合金を内部酸化す ると，全体的に内部摩擦が低くなるとともに，ピークが完

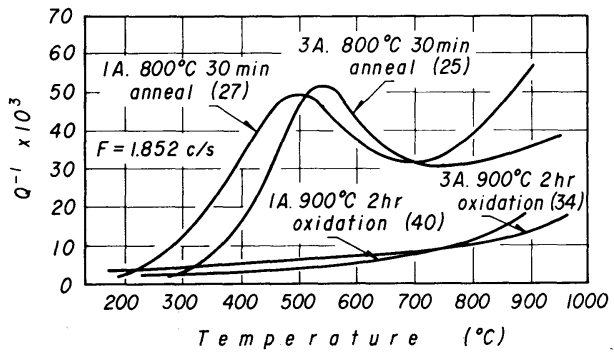

Fig. $7 Q^{-1}-\mathrm{T}$ curves of $1 \mathrm{~A}$ and $3 \mathrm{~A}$ before and after internal oxidation. The numbers in brackets show mean diameter of grains

全に消隇することが判った。この実験で $\mathrm{Al}_{2} \mathrm{O}_{3}$ 粒子の界面 が存在するから，この界面の内部摩擦が期待されたが，結 果はむしろ逆であった，この理由を調べるために，粒界に 括ける $\mathrm{Al}_{2} \mathrm{O}_{3}$ の存在状態を透過電子顕微鏡で 観察した.

Photo.8はこれを示す，すなわち，結晶粒界には粒内より も多量に $\mathrm{Al}_{2} \mathrm{O}_{3}$ 粒子が存在して打りここれが粒界粘性流動 を阻止するため, 粒界内部摩擦ピークが消隇したものと考 えられる．また本系合金では第 2 次相の量が少なく，その 界面の総面積が少ないこと，粒子が微細のため，あるいは 整合性が存在するために粒子界面の粘性流動による緩和現 象は本実験では無視し得るものと考学られる。

内部酸化を行なった $1 \mathrm{~A}, 3 \mathrm{~A}$ 合金を種々の加工度に冷 間加工し，次いで $900^{\circ} \mathrm{C} \times 1 \mathrm{hr}$ 焼なましたものの $Q^{-1}-\mathrm{T}$ 曲 線を Fig. 8 打よび Fig.9 亿示す。ささき述べたごとく， これらの試料は全て回復しているが, $\mathrm{Al}_{2} \mathrm{O}_{3}$ 粒子を連結す

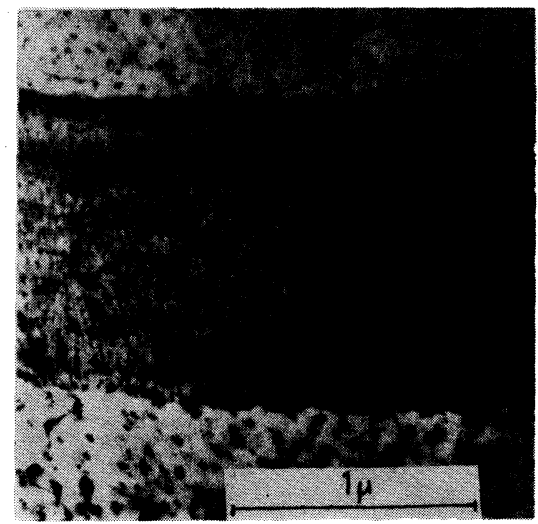

Photo. 8 Transmision electron micrograph of internally oxidized $1 \mathrm{~A}$ alloy. Banded contrast shows the grain boundary. $5 \%$ tensile elongation, $1000^{\circ} \mathrm{C} \times 1 \mathrm{hr}$ annealing $(\times 30000 \times 4 / 5)$

（24）門間，須藤；今井：金属学会会報，4(1965)，319. 
るように転位が存在しているところが内部酸化したままの 状熊と異なるところで, Figs.8,9 亿拈ける $750^{\circ} \mathrm{C}$ 付近の ピークは,これら $\mathrm{Al}_{2} \mathrm{O}_{3}$ 粒子を連結している転位の運動に 関与したものと思われる.

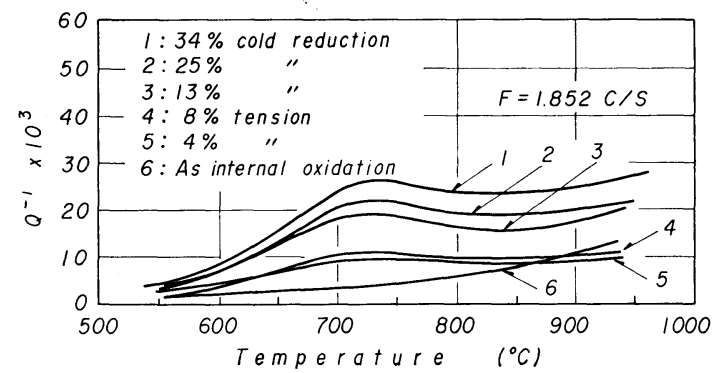

Fig.8 $Q^{-1}-\mathrm{T}$ curves of internally oxidized $1 \mathrm{~A}$ alloy after cold reduction followed by annealing at $900^{\circ} \mathrm{C}$ for $1 \mathrm{hr}$

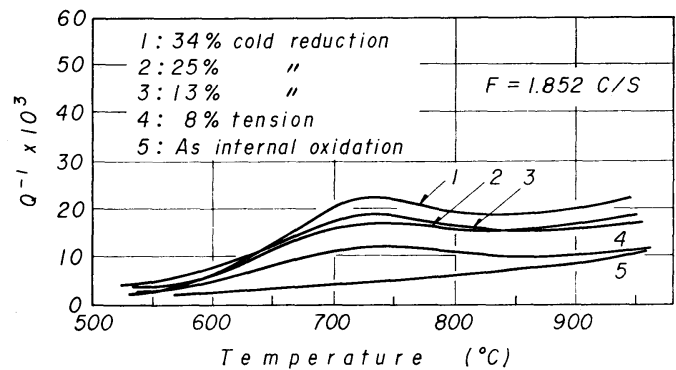

Fig.9 $Q^{-1}-\mathrm{T}$ curves of internally oxidized $3 \mathrm{~A}$ alloy after cold reduction followed by annealing at $900^{\circ} \mathrm{C}$ for $1 \mathrm{hr}$

Fig.10 は内部酸化 $\mathrm{Cu}-\mathrm{Al}_{2} \mathrm{O}_{3}$ 合金の加工度と，これを焼

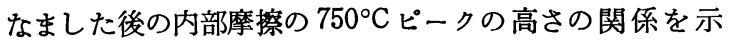

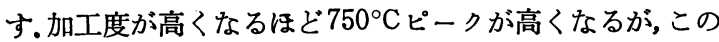
関係は Fig.4で示した機械的性質の傾向と一致している.

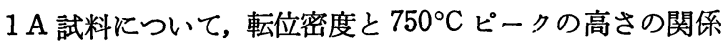
を求めたのが Fig.11 である. 観察した薄膜の厚みを全て 1000 Å と仮定したので，転位密度の值の精度については

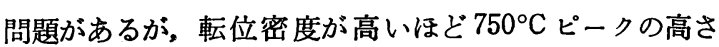
は高くなると考兄てよかろう，高温内部摩擦と転位密度の 関係を調べた研究はこれまで見当らないが，本実験の結果

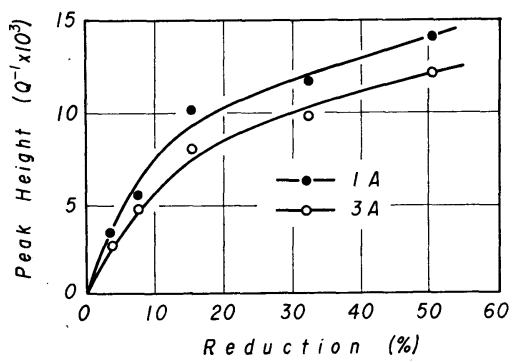

Fig.10 Relationships between reduction percent and $Q^{-1}$ peak hight of internally oxidized $1 \mathrm{~A}$ and $3 \mathrm{~A}$ alloys after cold reduction followed by annealing at $900^{\circ} \mathrm{C}$ for $1 \mathrm{hr}$
から, $750^{\circ} \mathrm{C}$ ピークは $\mathrm{Al}_{2} \mathrm{O}_{3}$ 粒子に釘止めされた転位の運 動に起因すると判断される.

Fig. 4 で示したよ その後さらに昇温してす軟化は進行しない，このことは高 温焼なましによっても， $\mathrm{Al}_{2} \mathrm{O}_{3}$ 粒子で釘止めされた転位は 容易に消隇しないことを示すが，Fig.12 は融点近傍まで 加熱してる， $750^{\circ} \mathrm{C}$ ピークの高さはほとんど変らず，前加 工度の差は一定に保たれることを示している.

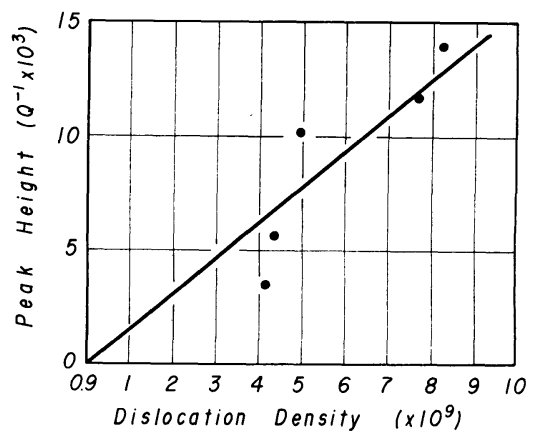

Fig.11 Relationship between dislocation density and $Q^{-1}$ peak hight of internally oxidized $1 \mathrm{~A}$ alloy after cold reduction followed by annealing at $900^{\circ} \mathrm{C}$ for $1 \mathrm{hr}$

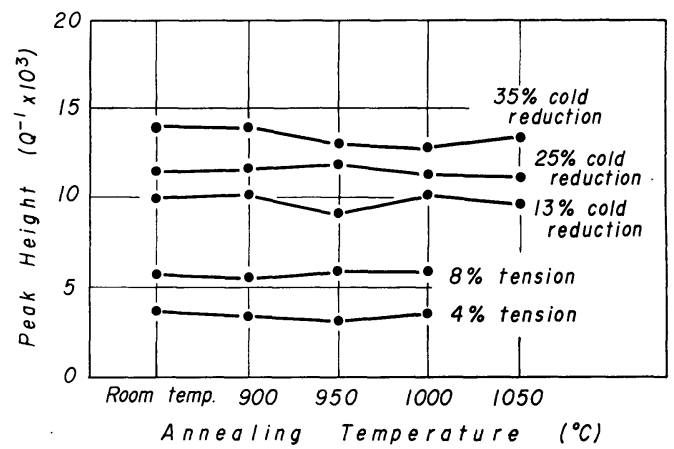

Fig. 12 Changs in $Q^{-1}$ peak hight of internally oxidized and cold worked $1 \mathrm{~A}$ alloy by annealing for $1 \mathrm{hr}$

Fig.13 は据り振動数 $F$ の対数とピークの温度 $T\left({ }^{\circ} \mathrm{K}\right)$ の 関係を求めたものである.このピークが熱活性化過程によ る緩和現象を示するのと考えて,

$$
\begin{aligned}
& F=F_{0} \exp (-H / R T) \\
& \text { ただし } F_{0}, H \text { は定数, } R \text { は気体定数 }
\end{aligned}
$$

なる式により活性化エネルギー $H$ を求めた。 すなわち Fig.13 の直線の傾斜はー $H / R$ を示すことになり,いずれの 加工度の場合もH の值として $70 \mathrm{kcal} / \mathrm{mol}$ を得た。これは $4 \mathrm{~A}$ 試料に対するクリープの活性化エネルギー， $82 \mathrm{kcal} /$ $\mathrm{mol}$ に近い值で, 純銅の拡散の活性化エネルギーQD 48 $\mathrm{kcal} / \mathrm{mol}^{(25)}$ 亿較べて明らかに大きい。

(25) 間間，須藤，及川：金属学会誌，28 (1964)，192. 


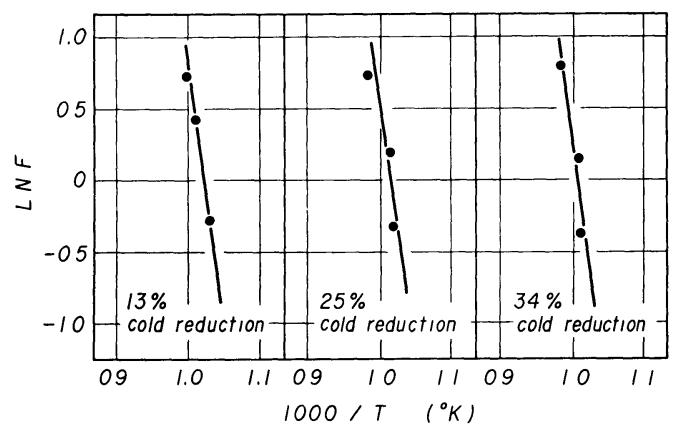

Fig. 13 Relationships between frequency $F$ and $Q^{-1}$ peak temperature $T$ in internally oxidized $1 \mathrm{~A}$ alloy after cold reduction followed by annealing at $900^{\circ} \mathrm{C}$ for $1 \mathrm{hr}$

\section{IV. 考察}

加工によって形成されたセル壁が $300^{\circ} \mathrm{C}$ 付近で容易に 消隇し， $600^{\circ} \mathrm{C}$ 以上，融点近傍に到るまでの焼なましです 安定な転位が残存すること，この残存転位の密度は加工度 とともに大となりこの転位の運動に起因すると思われる クリープおよび $750^{\circ} \mathrm{C}$ 内部摩擦ピークの緩 和過程の活性 化エネルギーがともにCu の自己拡散の活性化エネルギー の 1.5 2 倍の值を示す事実から次の事柄が考えられる.

転位と粒子の相互作用には次の 2 種類がある. 第 1 は Orowan のモデル(26)が示すよ5に，粒子の周辺にある距離 をへだててまつわりついている場合，第 2 は粒子に一端を 固着されている場合である，前者の転位は通常の上䄯運動 などによって比較的容易に消滅できる，後者の転位をつく ること,つまり転位を粒子表面に密着させるには本合金の 場合大きな力が必要であり，加工度がますとともに後者の 転位の数が多くなる. 粒子表面に密着した転位(いいかえ れば粒子表面に一端を有する転位)を粒子表面で動かすの

(26) E. Orowan: Discussion Symp.on Internal Stress, Inst.Met., London, (1947) , 451.
には大きな活性化エネルギーが必要であろう（転位を釘止 めしている粒子から外す過程す考えられるが，内部摩擦実 験のひずみは非常に小さいことから上の考光を採った)。な ぜなら硬質粒子は地質金属に較べて剛性率が高いので，こ の硬質粒子界面に沼って原子を拡散，移動させることは金 属地質中に批るよりる困難である場合が十分に考光られ る.この点に関する理論的ならびに実験的研究は未だ見知 しないが，興味ある問題と思われる.

な社分散粒子を含む合金のクリープの活性化エネルギー が高いことの説明としては従来次の説がある.

Meyers ら ${ }^{(8)}$ はSAP のクリープの活性化エネルギーが 高い理由として $\mathrm{Al}_{2} \mathrm{O}_{3}$ の “honeycomb”構造をあげている が，少なくとも内部酸化合金に対しては honeycomb 構造 は考光られないので，その説は一般的でない。

Wilcox ら ${ }^{(9)}$ は TD ニッケルに対して, $T>0.5 T_{m}\left(T_{m}\right.$ : $\mathrm{Ni}$ の融点, $\left.{ }^{\circ} \mathrm{K}\right)$ では結晶粒界之りがクリープの主な機構と 考えている.上記合金は微細結晶よりなるので，粒界之り 説す否定できないが，活性化エネルギーが高いことの説明 はなく，また本実験の $\mathrm{Cu}-\mathrm{Al}_{2} \mathrm{O}_{3}$ 合金に対しては，内部摩 擦の実験が示すよ5に粒界の寄与は重要でない。

\section{V. 総 括}

粒子分散型合金のクリープの活性化エネルギーが地質金 属の自己拡散の活性化エネルギーに較べて著しく大きい事 実に興味をるって, $\mathrm{Cu}-\mathrm{Al}_{2} \mathrm{O}_{3}$ 合金を用い,クリープと内部 摩擦の実験を行ない，両者の結果を対比して次の推論を得 た。

分散度の高い粒子を含む合金のクリープの律速過程は， 粒子の表面に密着している転位を粒子表面上で移動させる 過程にあると思われる。

な打本実験の遂行に当り，電子顕微鏡観察，その他に協 力された本学科 根本 実博士, 伊東祥雄工学士の労を感 謝する。 